\title{
US backs revamp of nuclear warheads
}

The US government is pushing ahead with a plan to overhaul its nuclear stockpile, despite a scientific review showing that existing warheads will last at least another half-century.

On 1 December, the National Nuclear Security Administration - the agency that oversees the US nuclear stockpile - announced that it will pursue plans to develop a new Reliable Replacement Warhead (RRW), which it claims will be safer and more robust than current designs. But the announcement came just two days after the release of research showing that the plutonium in existing warheads has a shelf-life of at least a century. Most warheads in the US stockpile are only about 20 years old.

Critics say the decision to proceed is an example of politics trumping science. "It is clear that the present stockpile is going to be reliable beyond our lifetime," says Jay Coghlan, executive director of Nuclear Watch, a watchdog group in Santa Fe, New Mexico. "It's not the science that rules, it's the special interests."

But officials maintain that the programme was never solely about replacing old warheads. "I believe the reasons for the RRW are in some ways independent of plutonium ageing," says Charles McMillan, associate director for weapons physics at Los Alamos National Laboratory in New Mexico. ${ }^{\alpha}$ RRW enables us to bring new technologies to the table."

Since 2004, the RRW concept has been gathering momentum - both at the nation's nuclear weapons labs and in Congress (see Nature 442, 18-21; 2006). The idea is to build a new generation of robust warheads to replace existing designs. They would be larger than existing warheads, but would have a greater margin of error, be easier to manufacture and indude more safeguards.

The proposed designs have mainly focused on making changes to the plutonium triggers, or pits, of the current warheads. Some argue that adding more plutonium or changing the way they are cast would result in a more stable, dependable trigger that could sit on the shelf for years without testing.

Officials have pushed for the programme to proceed quickly because of concerns that the ageing triggers on the current warheads might become unreliable within a few decades. The chief worry was that the constant stream of radiation that comes from the plutonium itself could create cavities in its crystalline structure, causing the weapon to fail.

But a trawl of old nuclear test data and a battery of lab tests have shown this isn't the case. Some of the 1,054 nuclear tests carried out by the United States before 1992 were done with ageing weapons, and the data helped scientists understand how older plutonium triggers behave. Meanwhile, researchers also discovered that artificially aged plutonium heals itself by shifting new atoms back into its crystalline lattice. The current generation of weapons can therefore last for at least 85-100 years.

These findings are likely to have implications elsewhere, especially in Britain, which is thought to have warheads similar to the US design. Other nations such as France use plutonium triggers and have stockpile stewardship programmes.

The findings were "a real surprise", says "The arguments with Raymond Jeanloz, a geologist which replacement Berkeley, and member of the warheads won JASONs - an independent congressional support scientific group that advises rity issues and that reviewed the work. "The labs have done an outstanding job."

The revised lifetimes call into question the need for an RRW programme, say many critics. RRW was sold to congressional supporters on the basis that the ageing stockpile would soon have to be replaced anyway. But as it will be in good condition for the conceivable future, such a plan now seems unnecessary, says Christopher Paine, a nuclear analyst at the Natural Resources Defense Council, an environmen-

\section{Bush faces rough ride over climate change}

With President George W. Bush and his administration continuing to avoid the issue, the courts and Congress are poised to shape climate-change policy in the United States.

Last week, the Supreme Court heard a high-profile case in which Massachus etts, along with numerous other states, cities and environmental groups, argued that the Environmental Protection Agency (EPA) should be forced to regulate greenhouse-gas emissions from cars and trucks as a pollutant. Massachus etts itself stands to lose $\mathbf{3 0 0}$ kilometres of its coastline as a result of the rise in sea levelas the planet warms.

The suitcan be read as an expression of many states' impatience with the federal government's inaction on climate change (see Nature 443, 486-487; 2006). Meanwhile, staff in the offices of Democratic politicians are sharpening their pencils for January, when the more liberal party takes over Congress, and supporters hope that climate-change bills will fly.

The verdict will be announced by the Supreme Court by the end of its term in June. Although the EPA trotted out the same oldadministration line that the "scientific uncertainty" was too great to act upon, the discussions

during the 29 Nowember hearing hint that the case might be decided on the technical grounds of standing - Massachusetts could sue the agency only if the harm suffered will be redressed if the EPA does act. The problem is that climate change

"I think no matter which way the law suit breaks, it will put more pressure on Congress." \section{issuch a large and} global problem that the emissions in question - from the tailpipes of US vehicles - may notmake a huge difference by

themselves. Massachusetts will probably still lose a considerable chunk of coastline.

Beneath the issue of standing, there seems to be a schism of opinion on more ideological grounds, with the more conservative judges looking likely to support the EPA, and the more liberal judges lining up with the Massachusetts group. With four justices on each side, Justice Anthony Kennedy, a noted moderate, may have the casting vote.

But many observers say that the decision itself will be less important than the buzz around the case. "I think no matter which way it breaks, it will putmore pressure on Congress," says Andrew Aulisi of the World Resources Institute, an environmental think-tank in Washington DC. If the Supreme Court sides with the EPA, he says, "everybody is going to throw up 
